\title{
CORRELATION OF HEARING IMPAIRMENT AND COMMUNICATION DISORDER AMONG GERIATRIC IN GERIATRIC CLINIC, DR. SOETOMO HOSPITAL SURABAYA
}

\author{
A Ratna Kartika M ${ }^{1}$, Nyilo Purnami ${ }^{2}$, Paulus Liben ${ }^{3}$ \\ ${ }^{1}$ Medical Doctor Program, ${ }^{2}$ Department of Otorhinolaryngology - Head and Neck Surgery, \\ ${ }^{3}$ Department of Medical Physiology, Faculty of Medicine, Airlangga University, Surabaya
}

\begin{abstract}
ABSTRAK
Tujuan dari penelitian ini adalah untuk menganalisis hubungan antara gangguan pendengaran dan gangguan komunikasi di antara geriatri di Geriatri Clinic, Dr. Soetomo. Sebuah desain studi cross-sectional acak telah digunakan dalam penelitian ini. Analisis dilakukan dengan mengisi beberapa kuesioner dan wawancara dengan beberapa pasien yang dipilih secara acak menurut conditons yang telah ditentukan. Data dikumpulkan dan ditinjau untuk faktor, yang dianggap sebagai faktor risiko gangguan pendengaran dan kualitas hidup kerusakan. Analisis statistik dilakukan dengan menggunakan uji Exact Fisher menggunakan SPSS versi Program 17. Hasil penelitian menunjukkan korelasi antara gangguan pendengaran dan kualitas hidup dan komunikasi sosial ( $p=0.033$, OR=6.11). Namun, tidak ada korelasi antara gangguan pendengaran dengan diabetes mellitus $(p=0,255)$, hipertensi $(p=0,565)$, dan lingkungan yang bising $(p=0,689)$. Kesimpulannya, penelitian menunjukkan bahwa ada hubungan antara gangguan pendengaran dan gangguan komunikasi. (FMI 2015;51:277-280)
\end{abstract}

Kata kunci: gangguan pendengaran, kualitas hidup, komunikasi sosial

\begin{abstract}
The objective of this study was to analyze correlation between hearing impairment and communication disorder among geriatrics in Geriatric Clinic, Dr. Soetomo Hospital. A randomized cross-sectional study design has been used in this study. Analysis was done by filling in some questionnaire and interview to some patients who were randomly selected according to predetermined condition. The data were collected and reviewed for the factors, which were assumed as risk factors of hearing disorder and life's quality deterioration. Statistical analysis was performed using Fisher's Exact Test using SPSS program version 17. Results showed correlation between hearing impairment and the quality of life and social communication $(p=0.033$, OR=6.11). However, there was no correlation between hearing impairment with diabetes mellitus $(p=0.255)$, with hypertension $(p=0.565)$, and noisy environment $(p=0.689)$. In conclusion, the study showed that there is correlation between hearing impairment and communication disorder.(FMI 2015;51:277-280)
\end{abstract}

Keywords: hearing impairment, quality of life, social communication

Correspondence: A Ratna Kartika, Medical Doctor Program, Faculty of Medicine, Airlangga University, J1 Prof dr Moestopo 47, Surabaya 60131, Indonesia.

\section{INTRODUCTION}

Hearing loss is a condition of reduced function of hearing in one or both sides of the ear. Hearing loss can occur without associated with age and depending on the clinical manifestations that occur. In the normal process of hearing loss, especially the decline in hearing ability, starts at the age of 20 years (CDC 2007) and only apparent after the age of 60 years. Globally, hearing loss in the elderly reached $30-45 \%$ of the total population aged 65 to 75 years. This number continues to rise until it reaches $50 \%$ of he population over the age of 75 years. In hearing loss, deafness rarely occurs in both ears. The proportion of $30 \%$ showed total deafness on only one side of the ears in people with age above 85 years (NIDCD 2002). In particular, hearing loss has been diagnosed definitely as presbycusis, reaching 8:48\% in 2005 in Indonesia (Suwento 2001).

Hearing loss is a condition where a person's auditory function declines progressively over a certain period of time (Paparela 1989). Hearing loss can occur bilaterally symmetrical or not, depending on the clinical manifestations of existing and the environment around the patient. Hearing loss can be observed most clearly in the elderly. Difficulty in communicating is one of the direct effects of the loss of hearing function. Often the interlocutors of the patient must adjust intonation and volume in communicating with the patient. This is of course one of the obstacles in achieving an effective communication within the community and can affect the quality of life psychologically (Hidalgo et al 2008). 
Basically, there is no specific ways to improve the condition of ear disorder caused primarily by age. What we can do is to attempt hearing rehabilitation (Soetjipto 2007). Rehabilitation can be done by placing hearing aid in accordance with the needs of the patient. Hearing aid is basically serves to reinforce (amplify) sounds that are around the user. Lip reading can also be studied to facilitate people with advanced hearing impairment in communication (Dewi 2007).

Treatment of the disorder depends on the cause of auditory function. If the function of conductive hearing disorder caused by the presence of middle ear fluid or dirt in the ear canal, then the treatment will be the disposal of the liquid and the dirt. If the cause cannot be resolved, the use hearing aids or cochlear transplant is sometimes suggested. Treatment or prevention must be done quickly so that hearing loss will not be more severe and does not affect the social life of patients (Soetjipto 2007).

This study was observed the relationship of hearing loss in elderly people's quality of life at the Dr. Soetomo Hospital since there was no definitive data that can be used as a reference in improving the quality of life of older persons in regards with hearing loss. The results of this study are expected to provide information for improving the quality of life as well as for further research.

\section{MATERIALS AND METHODS}

This study was an explanatory observational prospective study using cross sectional design. The population was all geriatric patients who were examined and underwent treatment at Geriatric Clinic, Dr. Soetomo Hospital between July and September 2010. The number of samples required in this study was minimally number 15. In this study, 30 samples were obtained. Sample criteria were age over 60 years and underwent examination at Geriatric Clinic, Dr. Soetomo Hospital, have complete medical records filled out by health workers, and willing to be a sample as well as to cooperate in the implementation of the study.

Data were taken during office hours at Geriatric Clinic, Dr. Soetomo Hospital. The subjects were asked to fill out a questionnaire after submitting informed consent to for data collecting. In addition to using the data obtained from questionnaire, medical record data from the Geriatric Clinic, Dr. Soetomo Hospital, which includes identity data and medical history of the patient. Data were analyzed based on existing variables using frequency distribution and Fishe's Exact Test using SPSS version 17 to determine correlations between variables. The frequency distribution can be computerized to facilitate research process.

\section{RESULTS}

From 30 samples taken in random to fill the questionnaires, there was a quite balanced ratio between male and female patients, where more patients were female (16) and male patients were 14. Most of the patients aged 75-79 years. Mean age of all respondents was 74.3 years, the median of was 75 years old. Most frequent age was 76 years in 4 patients. The minimum age was 68 and the maximum was 80 years.

Based on the results of questionnaires distributed to 30 patients and 30 patients' family, $43.3 \%$ of the patients had complaints of hearing impairment and $63.3 \%$ of the patients' family reported hearing loss of their family member, which was not realized by the patients themselves. Regarding the quality of life and social communication, 30 patients and 30 family members showed similar response regarding the quality of social communication with the patient's environment.

Table 1. Distribution of patients with impaired quality of life and social communications in Geriatric Clinic, Dr. Soetomo Hospital

\begin{tabular}{lcc}
\hline & Frequency & Percentage \\
\hline $\begin{array}{l}\text { Subject (patients) with symptoms of } \\
\text { life quality and social communication }\end{array}$ & 16 & $53.3 \%$ \\
disorder & & \\
$\begin{array}{l}\text { Subject (patients) without symptoms of } \\
\text { life quality and social communication }\end{array}$ & 14 & $46.7 \%$ \\
disorder & & \\
\hline Total & 30 & $100 \%$ \\
\hline
\end{tabular}

Data analysis used Fisher's Exact Test on the variables of hearing loss and impaired social communication of the patients, revealing $\mathrm{p}$ value of 0.033 .

Table 2. Distribution of patients' family complaints with impaired quality of life and social communications in Geriatric Clinic, Dr. Soetomo Hospital

\begin{tabular}{lcc}
\hline & Frequency & Percentage \\
\hline $\begin{array}{l}\text { Subject (patients) with symptoms of life } \\
\text { quality and social communication } \\
\text { disorder }\end{array}$ & 16 & $53.3 \%$ \\
$\begin{array}{l}\text { Subject (patients) without symptoms of } \\
\text { life quality and social communication }\end{array}$ & 14 & \\
disorder & & \\
\hline Total & 30 & $100 \%$ \\
\hline
\end{tabular}

Data analysis using Fisher's Exact Test on hearing loss and impaired social communication on the side of the family revealed $p$-value $=0.000$. Correlation was found 
between the decline in the quality of life and social communication in hearing loss patients in Geriatric Clinic, Dr. Soetomo Hospital. Odds ratio for the correlation was 6.111 , indicating that individuals with hearing loss have a risk of decreased quality of life and social communication disorders as much as 6.111 times higher than those who did not experience such problems. In addition, from 30 samples, 27 (90\%) had a history of hypertension and were still undergoing treatment in the Geriatric Clinic, Dr. Soetomo Hospital. Using Fisher's Exact Test the p value between hearing loss and exposure to noisy environments was found to be 0.565 , indicating no correlation between history of hypertensive disease and hearing loss.

Table 3. Distribution of hypertensive patients in Geriatric Clinic, Dr. Soetomo Hospital

\begin{tabular}{lcc}
\hline & Frequency & Percentage \\
\hline With hypertension & 27 & $90 \%$ \\
Without hypertension & 3 & $10 \%$ \\
\hline Total & 30 & $100 \%$ \\
\hline
\end{tabular}

In this study, from 30 samples ten $(33.3 \%)$ were found to suffering from diabetes mellitus. Fisher's Exact Test on the variables of hearing loss and exposure to noisy environments revealed $\mathrm{p}$ value 0.255 , showing no correlation between diabetes mellitus and hearing loss.

Table 4. Distribution of patients with diabetes mellitus in Geriatric Clinic, Dr. Soetomo Hospital

\begin{tabular}{lcc}
\hline & Frequency & Percentage \\
\hline With diabetes mellitus & 10 & $33.3 \%$ \\
Without diabetes mellitus & 20 & $66.7 \%$ \\
\hline Total & 30 & $100 \%$ \\
\hline
\end{tabular}

It was found that only 8 patients who had long-term interaction with the previously noisy environments. Using Fisher's Exact Test, the variables of hearing loss and exposure to noisy environments had $\mathrm{p}$ value of 0.689 , showing no correlation between exposure to environmental noise and hearing impairment.

Table 5. Distribution of patients with noisy environment in Geriatric Clinic, Dr Soetomo Hospital

\begin{tabular}{lcc}
\hline & Frequency & Percentage \\
\hline With noisy environment & 8 & $26.7 \%$ \\
Without noisy environment & 22 & $73.3 \%$ \\
\hline Total & 30 & $100 \%$ \\
\hline
\end{tabular}

\section{DISCUSSION}

Status determination of hearing loss was obtained from questionnaires distributed both to patients and family/ patient attendants. Different results were obtained in two groups of data. From the results of the questionnaire, $43.3 \%$ of the patients felt hearing loss after answering some initial questions asked. Whereas, for the same case, $63.3 \%$ family of the patients stated that the patient has a hearing loss. With respect to the quality of life and social communication of the patients, it was found that $53.3 \%$ had decreased quality of life and social communication. The patients' or the patients' family/attendants also provided similar statement in this regard.

The results showed difference between the patients with the environmental assessment of the status hearing. Hearing loss is felt by people around the patient than the patients themselves. This is due to the disruption of information/communication exchange between the patients and the environment which was not actually realized by the patient. Indirectly, this will reduce the frequency of speaking of the people around the patient and will affect the patients' social skills (Suwento 2001).

As can be proved by the finding in this study, hearing loss also affects the decrease of life and social quality of the patients. Decreased quality of life and social communication is measured using the parameters of how the patient has relations with the people and environment around as well as how the quality of emotion that the patient feels. Prolonged stress due to loss of family, loneliness, and some other social conditions that weighed the emotions of patients are factors that affect the quality of life of the patients. In advanced decrease of the quality of life and social, the patients withdraw themselves, avoid family, even avoid public places due to embarrassment on the condition of his hearing (CMAJ 2007).

Both the patient and family/companion also feel the effects of hearing loss that affect the quality of interpersonal communication. In a further interview a family/companion of the patient has a tendency to reduce the frequency of communication with the patient. Socially, it is tantamount as one of the conditions that affect patients' mental in socializing. Family is supposed to spearhead the promotion of quality of life of the elderly (Lotfi et al 2009). In this study, 92.3\% of patients had a history of hypertension and only $33.3 \%$ with a history of diabetes mellitus. Both of these diseases affect vascular condition of patients who also have an impact on vascularization of the middle and inner ear (Katz 2002).

Both these factors were included as predisposing factor for hearing loss in elderly patients as it will affect vascularization of inner and middle ear organs that affect on the quality of those organs to process sound 
vibration stimuli (El Dib et al 2008). However, this study found no relationship between those factors. History of exposure to noisy environments was obtained from questionnaires about their jobs and environment where the patient lived.

Exposure to loud noise for a long time and continuous is the main cause of most of hearing loss (NIH 2003). This is due to decreased tympanic membrane elasticity, thereby reducing the patient's quality of sound wave vibration propagation (Soetjipto 2010). However, this study found no correlation between exposure to environmental noise affecting hearing loss impact on the quality of life and social life of the patients. Nevertheless, some studies found that age, gender, hypertension, diabetes mellitus, excessive noise exposure and hearing loss can lead to decreased quality of life and a person's social communication (CMAJ 2007).

Such discrepancy between the results of this study and those of the previous ones probably due to the limited number of samples, inadequate sample selection, and conditioning of patients in receiving the questionnaire. In this study, assessment of hearing loss status was confirmed by the results of questionnaires. The use of the questionnaire only provided a rough idea of one's hearing status. Hearing status can be confirmed using audiometric tests or similar hearing tests. The existence of these limitations leads to less accurate hearing status used in this study.

A deeper understanding on the patients' quality of life and communication requires further approach to obtain clear picture about the psychosocial condition of the patient. In this study, quality of life and patient communication was generally assessed using questionnaire. Further understanding is needed to obtain more exact status on psychosocial condition grading of the patient.

\section{CONCLUSION}

Communication disorder correlates with loss of quality of life in patients with hearing loss. Hearing quality affects the activity of one's communication with its surroundings. History of hypertension, diabetes mellitus, and exposure to environmental noise are not related to the status of hearing loss that affects the quality of life and communication disorders.

\section{REFERENCES}

Bance M (2007). Hearing and aging. CMAJ 176, $925-$ 927

Centers for Disease Control and Prevention (CDC) (2007). Hearing Loss. Available from http://www.cdc. gov/ncbddd/dd/ddhi. htm. Accessed May 4, 2010

Dewi YA (2007). Presbiakusis. Dissertation. Universitas Padjajaran, Bandung, p 1

El Dib RP, Silva EM, Morais JF, Trevisani VF (2008). Prevalence of high frequency hearing loss consistent with noise exposure among people working with sound systems and general population in Brazil: a cross-sectional study. BMC Public Health 8, 151

Hidalgo JL, Gras CB, Lapeira JMT, Martínez IP, Verdejo MAL, Rabadán FE, Puime AO (2008). The hearing-dependent daily activities scale to evaluate impact of hearing loss in older people. Ann Fam Med 6, 441-447

Katz J (2002). Handbook of Clinical Audiology 5th ed, Philadelpia, Lippincott Williams \& Wilkins, p 597598

Lotfi Y, Mehrkian S, Moossavi A, Faghih-Zadeh S (2009). Quality of life improvement in hearingimpaired elderly people after wearing a hearing aid. Arch Iran Med 12, 365-370

National Institute on Deafness and Other Communication Disorders (NIDCD) (2002). Presbycusis. Available from http://www.nidcd.nih.gov/ health/hearing/ pres-bycusis.asp. Accessed May 4, 2010

Soetjipto, Damayanti, Gangguan Pendengaran Akibat Bising /GPAB (Noise Induced Hearing Loss/NIHL) (2007), Available from:http://www.ketulian.com/v1/ web/index.php?to=article\&id $=15$. Accessed 4th May 2010

Soetjipto, Damayanti (2010). Presbikusis. vailable from: http://www. ketulian. com/ v1/web/index.php?to= article\&id=16. Accessed May 4, 2010

Suwento RH (2001). Gangguan pendengaran pada geriatri. In: Tim Buku Ajar Ilmu Kesehatan (eds). Buku Ajar Ilmu Kesehatan Telinga Hidung Tenggorok Kepala Leher, Jakarta, Fakultas Kedokteran Universitas Indonesia, p 33-34 